\title{
THE POTENTIAL EFFECTS OF BREXIT ON THE INTERNATIONAL TRADE OF THE UNITED KINGDOM ${ }^{105}$
}

\author{
Marko Tomljanović106 \\ Igor Cvečić ${ }^{107}$ \\ Ana Malnar ${ }^{108}$
}

https://doi.org/10.31410/itema.2018.283

\begin{abstract}
The process of the United Kingdom (UK) leaving the European Union, as a result of the 2016 referendum, brings a lot of uncertainties regarding the impacts of new regulations of trade relations between the UK and other EU member states as well as other countries worldwide. The purpose of this research is, based on a review of the UK's history as an EU member, and the analyses of its current international trade, to determine the potential effects of the process of the UK leaving the European Union to its future trade with the rest of the world. In this paper, four different models by which further trade relations between the United Kingdom and EU could be regulated are discussed. Each of these models has its advantages and disadvantages, and it is not possible to determine with certainty which one of them would be the most beneficial for the UK. Even though a large number of UK's trade partners are not EU members, it is evident that the trade with other countries worldwide can easily be a subjected to change. For that reason, the United Kingdom should primarily base its trade on relations with EU member states, with the assumption of further cooperation with other counties.
\end{abstract}

Keywords: BREXIT, EU, international trade, United Kingdom

\section{INTRODUCTION}

In 2016 the United Kingdom became the first EU state member who activated Article 50 of the Treaty on European Union ${ }^{109}$, and based on the referendum results, began the process of withdrawing from the $\mathrm{EU}^{110}$. The last phase of the exiting process should be finished in February 2019 when the UK will officially become a "former "state member. If the history of this country regarding European integration is taken into consideration, it is evident that the exiting process is merely an extension of a behavior pattern this country has had during the years, including special demands and needs based on their historical and economical success. ${ }^{11}$ The end of this process represents new economic, political and social challenges both for the United Kingdom and for the European Union. Furthermore, the trade aspect, as the focus of this paper, represents an important part of their future relations.

\footnotetext{
105 This paper is a part of the scientific project entitled "Liberalisation, integration, globalization and the afirmation of protectionism?" funded by the University of Rijeka.

${ }^{106}$ University of Rijeka, Faculty of Economics and Business, Ivana Filipovića 4, 51000 Rijeka, Croatia

${ }^{107}$ University of Rijeka, Faculty of Economics and Business, Ivana Filipovića 4, 51000 Rijeka, Croatia

${ }^{108}$ University of Rijeka, Faculty of Economics and Business, Ivana Filipovića 4, 51000 Rijeka, Croatia

${ }^{109}$ Implemented as one of the key changes of the Treaty of Lisbon from 2007. It implies that any Member State may decide to withdraw from the Union.

${ }^{110}$ Commonly known under the term Brexit. The referendum votes were 51,8\% in favour of leaving the EU.

${ }^{111}$ In fact, in 1975, shortly after entering the European Economic Community in 1973, Great Britain held a referendum about staying in the Community where $67.2 \%$ of votes were in favour of "remain".
} 
The core research problem emerges from the current inability to determine clear practices of the UK's international trade once they are no longer a member state of the EU. The aims of this research are to analyze the historical course of the UK's trade, and to determine the potential impact of Brexit on future international trade relations. The purpose of the research is to scientifically determine the potential perspectives of the UK's trade policy outside of the EU. In this paper, the descriptive analyses of key figures for the UK's international trade have been applied, which have been collected from relevant international databases (World Bank and The Observatory of Economic complexity). This research is based on the available data for the period 1973 to 2017.

After the initial considerations in which the key research elements are defined, the descriptive analysis of the UK's international trade has been conducted, and the potential effects of exiting process on the future flows of Britain's trade have been determined. The research is continued by determining potential directions of the UK's trade outside the EU. Lastly, the paper is concluded with final considerations representing the synthesis of scientifically based facts which emerged as a result of this research.

\section{ANALYSIS OF THE UNITED KINGDOM'S INTERNATIONAL TRADE}

The analysis of the UK's international trade has been based on the following indicators: (1) export and import of goods and services (\% GDP), (2) international trade balance (\% GDP), (3) foreign trade coverage ratio, and (4) the Terms of trade (ToT). While, the calculation of foreign trade coverage ratio is based on the following equation:

$\mathrm{k}(\mathrm{m})=(\mathrm{X}+\mathrm{M}) / \mathrm{Y}$

where $X$ represents export, $M$ represents import and $Y$ represents national income of a certain county.

Furthermore, the benefits of foreign trade are usually presented using the indicator ToT, which can be calculated as a ratio between import and export prices:

$\mathrm{Pm} / \mathrm{Px}[$ i.e. Px / Pm]

Where Pm represents import prices, and Px export prices.

The United Kingdom (UK) became a member state of European Economic Community in 1973, and since then it started developing strong trade relations with other members, primarily through the Customs Union [5]. Data from Appendix 1 illustrates, with a few exceptions, the constant increase in shares of import and export in its GDP which the UK made since 1973. For example, the export increased from initial $20.2 \%$ of GDP to $28.2 \%$ of GDP in the observed period, while the import has increased from initial $24.2 \%$ of GDP to $31.9 \%$ of GDP. In addition, it is possible to conclude that throughout this period, the UK was mainly an import-oriented country, and it mostly had a trade deficit. The trend in foreign trade coverage ratio indicates a higher importance of foreign trade in comparison with the beginning of the period. The average value of ToT leads to the conclusion that the UK benefited from its foreign trade throughout the whole observed period (the average value of ToT in the observed period is 180.6792), and those benefits are especially noticeable before the year 2000 . 
The UK's export mainly consists of cars (12\%), pharmaceutical drugs $(5.2 \%)$, gold (4\%), gas turbines $(3.5 \%)$ and aircraft parts $(2.5 \%)$. On the other hand, the UK mostly imports gold $(8.2 \%)$, cars $(7.8 \%)$, pharmaceutical drugs $(3.1 \%)$ and car parts $(2.5 \%)$ [8]. The UK's most important trade partners, with $14 \%$ of total export, are the United States. Moreover, it is important to mention that six out of fifteen UK's most important trade partners are countries outside the EU, and are as such the destinations for almost $30 \%$ of the UK's total export (Table $1)$.

Table 1: Top 15 United Kingdom's partners in export and import in 2017

$\begin{array}{clrlr}\text { No. } & \text { Export countries } & \text { \% of total export } & \text { Import countries } & \text { \% of total import } \\ 1 & \text { USA } & 14 & \text { GERMANY } & 14 \\ 2 & \text { GERMANY } & 9.5 & \text { CHINA } & 9.8 \\ 4 & \text { FRANCE } & 6 & \text { USA } & 7.5 \\ 5 & \text { NETHERLANDS } & 6 & \text { NETHERLANDS } & 7.3 \\ 6 & \text { SWITZERLAND } & 5.1 & \text { FRANCE } & 5.8 \\ 7 & \text { IRELAND } & 5.1 & \text { BELGIUM } & 5.3 \\ 8 & \text { CHINA } & 5 & \text { LUXEMBOURG } & 5.3 \\ 9 & \text { BELGIUM } & 4.7 & \text { ITALY } & 3.9 \\ 10 & \text { LUXEMBOURG } & 4.7 & \text { SPAIN } & 3.4 \\ 11 & \text { SPAIN } & 3.3 & \text { IRELAND } & 3 \\ 12 & \text { ITALY } & 3.2 & \text { NORWAY } & 2.9 \\ 13 & \text { HONG KONG } & 1.9 & \text { JAPAN } & 2.6 \\ 14 & \text { JAPAN } & 1.7 & \text { TURKEY } & 2.5 \\ 15 & \text { UNITED ARAB } & 1.7 & \text { SWTZERLAND } & 2.2\end{array}$

Source: developed by authors based on The Observatory of Economic Complexity (2018)

Similar to export, $27.5 \%$ of the UK's total import comes from the non-EU countries, mostly from China and the USA. This kind of import and export structure indicates that the UK is sufficiently connected with global partners outside the EU. The situation mentioned above should represent the base for the development of new trade agreements after the exiting process finalizes. Nevertheless, it should be noted that the current situation is a consequence of the UK's integration in international trade as a whole. It is uncertain whether those trends will continue once the UK becomes an independent entity faced with the challenge of developing its own and separate trade relations with global partners.

\section{POTENTIAL EFFECTS OF BREXIT ON UNITED KINGDOM'S TRADE POLICY}

The concrete effects of Brexit will be seen in the long run. In the near future, changes are possible in the decision making process, regarding the trade and foreign direct investments, changes in headquarters (from the EU to the United Kingdom and vice versa, depending on company's business orientation) as well as the effects on export due to the devaluation of the currency [6]. Having the long-term consequences in mind, the UK will, due to Brexit, find itself outside the European Single Market and the Customs Union; therefore, some tariff and nontariff barriers will have to be implemented, which will increase the costs of international trade. However, such situation offers new possibilities of developing trade partnerships outside of Europe for the UK. Having Britain's current trade relations in mind, the question of 
strengthening trade relations with the USA and other members and of NAFTA, ${ }^{112}$ creating a free trade zone along with the Commonwealth countries, ${ }^{113}$ poses itself as a possibility.

The data mentioned earlier demonstrates the connection between the United Kingdom and trade partners outside the EU, in accordance with the UK's current trade policy. According to it, a question emerges: should the import share from countries of South America, Asia, and certain developing countries have been higher during the last three or four years [7]? The stated does not necessarily have to represent a high-risk level because the lower contribution to trade of those countries can be explained by certain economic cycles and by adjustments on the market in China. That thesis is supported by the IMF reports from 2016 [4], which show positive growth perspectives for economies in Asia, Middle East, Africa and Central Europe (Appendix 2). Based on the report, in the period between 2016 and 2021, China and Hong Kong should have the highest growth of GDP (in average, 6\%), followed by, countries from the Middle East and North Africa, while the lowest growth is predicted for countries from the ex-Soviet Union.

Furthermore, it is necessary to consider the future trends regarding the UK's export (Appendix 3 ) and its future destinations (Appendix 4). Conducted research illustrates that the UK's export will reach the highest growth rates in the period between 2014 and 2020, while in the long run (between 2021 and 2030) the growth slowdown can be expected. Higher growth in the near future will mostly be a result of higher export in fast growing countries $(13 \%$ in 2030 , which is three times larger rate than in 1999; 4\%) E7 ${ }^{114}$, especially China and India, due to the fast economic growth in those countries. However, the European Union will remain UK's most important trade partner [6]. In fact, the trade with developing countries (especially export) can easily face changes because of unexpected events on foreign and domestic markets. This will not be the case with export-oriented countries whose economies are much more similar to the UK economy. Due to that, it is important for the UK to maintain current trade relations with the EU member states, as well as with the USA. The politics of president Donald Trump will surely have a big impact on the development of future trade relations with the USA as he stated that Brexit can only have positive effects on British trade, and has announced some new trade agreements between the USA and the UK in the future [3]. With his previous decisions and protectionist approach in mind, it is not possible to claim with a great certainty whether those trade agreements will be realized.

\section{DEVELOPMENT PERSPECTIVES OF UNITED KINGDOM'S TRADE RELATIONS AFTER THE WITHDRAWAL FROM THE EU}

The development perspective for the UK's trade relations after Brexit is complicated and uncertain, and due to that it is not possible to make a singular conclusion. In this paper four different models of the future UK trade are taken into consideration; Norwegian Model, Swiss Model, EFTA Model and WTO model.

By implementing the Norwegian Model, the UK should organize its trade in accordance with rules and principles of the European Economic Area (EEA), founded in 1994, which gives the opportunity to countries outside the EU to (mostly) participate in the European Single Market.

\footnotetext{
${ }^{112}$ North American Free Trade Agreement, member states are USA, Mexico, Canada. However, the protectionist approach that the USA has and the possible implementation of tariffs in certain sectors bring the existence of this organization into question.

${ }^{113}$ Common name for a community of 53 countries, mostly former British colonies.

114 Common name for a group of fast-growing countries: China, India, Brazil, Mexico, Russia, Indonesia and Turkey.
} 
Among the EEA members ${ }^{115}$ there is a free movement of goods, services, labour and capital ${ }^{116}$ [1]. Even though there is free trade between the countries within the EEA, they are not a part of Customs Union, which enables them to determine the way of conducting their own trade policy for countries outside of the $\mathrm{EU}^{117}$. Some restrictions of this model are: the implementation of rules of origin in export, the possibility of the EU implementing antidumping measures, payments to the EU funds for regional development. If the UK embraces this model, it would certainly have to pay for its participation in the EEA.

Furthermore, it is possible to determine future trade relations by implementing the Swiss Model $^{118}$, whose key advantages are the flexibility and freedom in the decision making process regarding the participation in EU initiatives, as well as the similar level of integration and trade of goods as in the case of the EEA ${ }^{119}$ membership [2]. Implementing the Swiss Model could be beneficial if the UK wants to have more freedom in deciding in which segments of EU policies it wants to participate. On the other hand, this kind of "a la carte" approach does not bring the same level of market approach as it does with the membership in the EEA, which could in future cause extra expenses for the UK. The models are based on solutions which enabled future economic integration with other EU member states, and partial participation in the European Single Market ${ }^{120}$.

EFTA approach is a possible solution, based on which the British goods exported to the EU, as well as the ones imported from the EU, would not be charged with tariffs. However, the free movement of labour or services would not be possible. Due to the fact that the UK in this case would not be a part of the Single Market it can be assumed that there could be some dissents in certain EU directives and in non-tariff barriers to the trade. If changes in core paradigms of the EFTA $^{121}$ would happen, primarily regarding the non-tariff barriers and free movement of labour and capital, it can be concluded that this approach would not be an adequate solution for the UK because the only benefit in this case is the absence of tariff barriers which is not nearly enough.

In the fourth model, if the UK and the EU do not make any of the prior mentioned agreements, the future trade of the UK will be regulated based on the rules of the World Trade Organization (WTO), by which export to the EU, and other state members of the WTO, would be a subject to tariffs based on a principle of the most favored nation. Due to the fact that the WTO has not

\footnotetext{
${ }^{115}$ Current members of the EEA are EU state members, along with Iceland, Norway and Liechtenstein.

${ }^{116}$ On the other hand, the limitations of the agreement refer to agriculture and fishing, Customs Union, common trade, common foreign and security policy, judicial system, internal affairs, and economic and monetary union.

${ }^{117}$ By withdrawing from the EU, the United Kingdom automatically stops being a member of the EEA. If the UK wants to once again become a member of the EEA, it would first need to enter the EFTA, which is questionable because in that case, the UK would have to accept the EU legislation, continue with payments and accept the jurisdiction of the European Court of Justice and the European Commission.

${ }^{118}$ Even though it is not a member state of the EU or the EEA Switzerland has arranged its trade relations with the EU with bilateral agreements, and by being a member of European Free Trade Agreement (EFTA) it has the right to trade with all non-agricultural goods among all state members of the EU.

${ }^{119}$ Switzerland decided to be a part of integration with the EU state members by accepting and applying most of the EU directives, it also pays a contribution to the European Regional Funds.

${ }^{120}$ The reason why Brexit was carried out was the fact that the UK voters were unsatisfied with its position in the EU, and they decided to make some changes regarding their participation in the Union. Due to that, it is possible to question if the prior mentioned models represent an acceptable change in comparison to the previous level of integration they were clearly unsatisfied with.

${ }^{121}$ EFTA started with its activities to accomplish the goal of reducing tariffs in order to reduce the costs of trade and promoting international economic integrations. However, with the affirmation of WTO, EU and bilateral agreements the focus in making the trade relations has been put on removing the non-tariff barriers and on free movement of labour and capital.
} 
made a progress in market liberalization of services, such as the European Union did, the prior mentioned could block access to the EU market of services for the British companies. Furthermore, the WTO does not assume the free movement of labour, but there are no restrictions in the movement of capital [16]. One of the positive aspects of this model is the possibility that the UK sets its own tariffs for import. In case the trade is regulated only by the WTO rules, the UK would be able to set the same tariffs as the EU did in earlier stages, which could possibly lead to their decrease ${ }^{122}$. In addition, by rejecting the participation in a higher level of integration, the UK would gain greater political power ${ }^{123}$.

The summary display of the prior mentioned models is given in Table 2 .

Table 2: Trade possibilities for United Kingdom outside of EU

\begin{tabular}{|c|c|c|}
\hline Model & For & Against \\
\hline $\begin{array}{l}\text { EEA - Norwegian } \\
\text { Model }\end{array}$ & $\begin{array}{l}\text { being a part of the Single } \\
\text { Market } \\
\text { the possibility to make trade } \\
\text { relations independently from } \\
\text { EU }\end{array}$ & $\begin{array}{l}\text { application of the Single Market } \\
\text { rules without the possibility to } \\
\text { influence their decision making } \\
\text { process } \\
\text { - respecting the rules of origin for } \\
\text { the export of goods } \\
\text { the possibility to apply anti- } \\
\text { dumping measures of the EU } \\
\text { - deposing funds to the EU budget }\end{array}$ \\
\hline Swiss Model & $\begin{array}{l}\text { - free movement of goods and } \\
\text { people within the EU } \\
\text { the possibility of making } \\
\text { trade relations independently } \\
\text { from the EU } \\
\text { - the possibility of non- } \\
\text { participating in EU programs } \\
\text { on a case basis }\end{array}$ & $\begin{array}{l}\text { obeying the EU rules of origin } \\
\text { based on bilateral agreements, } \\
\text { without participating in their } \\
\text { decision making process } \\
\text { no agreement with the EU } \\
\text { regarding the trade of services } \\
\text { paying the fees for participating } \\
\text { in EU programs }\end{array}$ \\
\hline EFTA & $\begin{array}{l}\text { - free trade of goods within the } \\
\text { EU } \\
\text { the possibility of making } \\
\text { trade relations independently } \\
\text { from the EU } \\
\text { no obligation to accept } \\
\text { economic policies and } \\
\text { regulations of the EU } \\
\text { no obligation to contribute to } \\
\text { the EU budget }\end{array}$ & $\begin{array}{l}\text { no free movement of people } \\
\text { within EU } \\
\text { no access to the EU market of } \\
\text { services } \\
\text { goods exported to the EU need to } \\
\text { comply to EU standards for } \\
\text { products }\end{array}$ \\
\hline
\end{tabular}

\footnotetext{
${ }^{122}$ In case of import tariffs the UK would implement, they would be lower than the EU ones, and that would have a positive effect on its consumers. However, this kind of approach would have a negative effect on British producers who would have bigger competition due to cheaper import.

${ }^{123}$ If the United Kingdom would stop being a part of the Single Market, they would be able to determine their own policies and standards, independently from the EU. It is important to note that every disagreement in prior mentioned policies could cause a non-tariff barrier which would make the trade more difficult and increase its costs.
} 


\begin{tabular}{|c|c|c|}
\hline WTO & $\begin{array}{l}\text { the possibility of making } \\
\text { trade relations independently } \\
\text { from the EU } \\
\text { no obligation to accept } \\
\text { economic policies and } \\
\text { regulations of the EU } \\
\text { no obligation to contribute to } \\
\text { the EU budget }\end{array}$ & $\begin{array}{l}\text { no free movement of people } \\
\text { within the EU } \\
\text { trade with the EU is based on the } \\
\text { principle of the most favored } \\
\text { nation and non-tariff barriers } \\
\text { from the WTO } \\
\text { - goods exported to the EU need to } \\
\text { comply to EU standards for } \\
\text { products } \\
\text { no access to the EU market of } \\
\text { services }\end{array}$ \\
\hline
\end{tabular}

Source: Developed by authors

\section{CONCLUSION}

The conducted research indicates key challenges for the United Kingdom's trade relations they might face once the process of Brexit is finalized. The efficiency of future trade flows and the adjustment to global trends will mostly depend on the choice of the right trade model and the adjustment of economic and political power holders to new conditions. The scientific contribution of this paper comes from an overview of Britain's international trade throughout the years and identification of key challenges and impacts of Brexit to the UK's future trade flows. Future research in this area should be oriented on quantifying the Brexit effects on economic growth and employment, as well as other macroeconomic indicators which will occur due to changes in the UK's trade paradigm.

\section{REFERENCES}

[1] European Parliament (2018), available http://www.europarl.europa.eu/factsheets/hr/sheet/169/europski-gospodarski-prostor-egpsvicarska-i-sjever

[2] EFTA, (2018), available on: http://www.efta.int/about-efta/the-efta-states

[3] Hughes, D (2017) Independent, Donald Trump: Brexit could be a good thing for both parties, Independent, available on: http://www.independent.co.uk/news/world/americas/us-politics/donald-trump-latestbrexit-european-union-act-together-uk-angela-merkel-a7663641.htm 1

[4] International Monetary Fund (IMF) (2016) IMF World Economic Outlook, Washington, D.C., United States, available on: http://www.imf.org/external/pubs/ft/weo/2016/02/

[5] Kandžija, V., Cvečić, I. (2010) Ekonomika i politika Europske unije, University of Rijeka, Faculty of Economics and Business, Rijeka, Republic of Croatia

[6] PricewaterhouseCoopers B.V. (2017) Brexit Monitor - The impact of Brexit on (global) trade, available on: https://www.pwc.nl/nl/brexit/documents/pwc-brexit-monitortrade.pdf

[7] Sentance, A. (2016) UK trade prospects after Brexit, in UK Economic Outlook November 2016, pp. 29 - 31, available on: https://www.pwc.co.uk/economic-services/ukeo/ukeonov16-trade-prospects-after- brexit.pdf

[8] The observatory of Economic Complexity (2018), available on: https://atlas.media.mit.edu/en/profile/country/gbr/

[9] World bank (1) (2018), https://data.worldbank.org/indicator/NE.EXP.GNFS.ZS
[10] World bank (2) (2018),
https://data.worldbank.org/indicator/NE.IMP.GNFS.ZS

$\begin{array}{ll}\text { available } & \text { on: } \\ \text { available } & \text { on: }\end{array}$




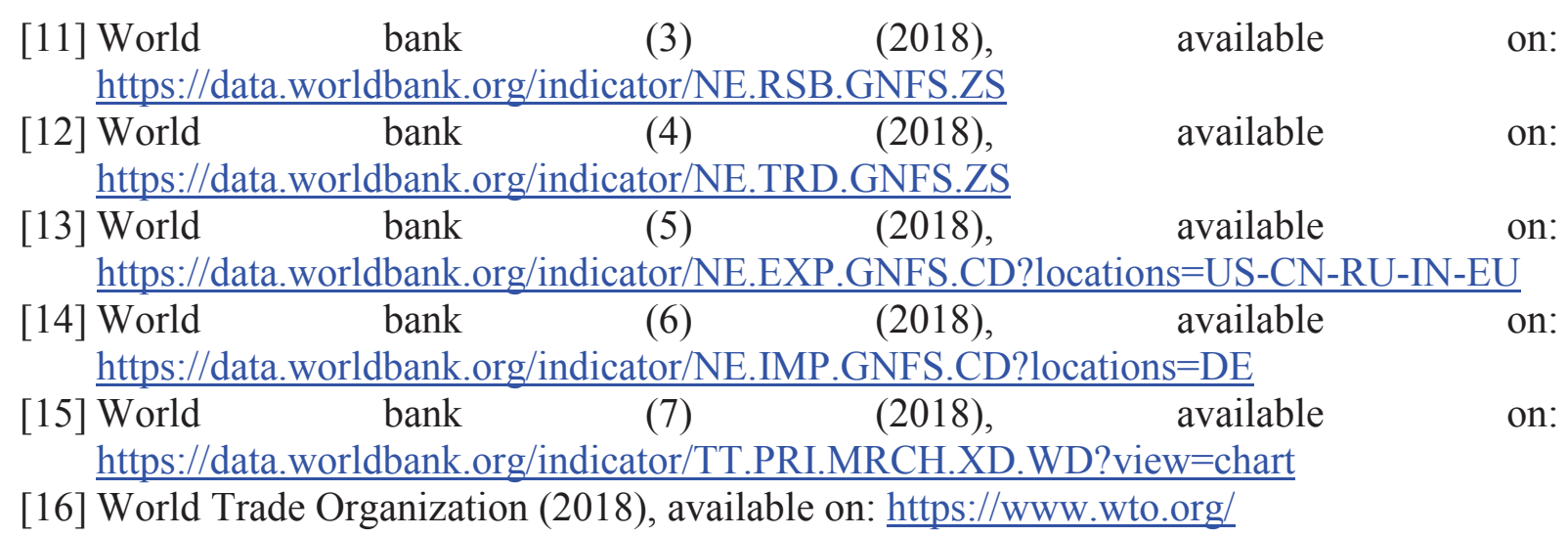




\section{APPENDICES}

Appendix 1 Key Trade Indicators of the United Kingdom in the Period 1973-2017

\begin{tabular}{|c|c|c|c|c|c|c|c|c|c|}
\hline Year & $\begin{array}{r}\text { GDP (US } \\
\text { dollars) }\end{array}$ & $\begin{array}{r}\text { Export } \\
\text { (\% of } \\
\text { GDP) }\end{array}$ & $\begin{array}{r}\text { Import } \\
\text { (\% of } \\
\text { GDP) }\end{array}$ & $\begin{array}{r}\text { Trade } \\
\text { balance } \\
(\% \text { of } \\
\text { GDP) } \\
\end{array}$ & $\begin{array}{r}\text { Export } \\
\text { (US } \\
\text { dollars) }\end{array}$ & $\begin{array}{r}\text { Import } \\
\text { (US } \\
\text { dollars) }\end{array}$ & $\begin{array}{r}\text { Export+ } \\
\text { Import } \\
\text { (US } \\
\text { dollars) } \\
\end{array}$ & $\begin{array}{r}\text { Foreign } \\
\text { Trade } \\
\text { Coefficie } \\
\text { nt }\end{array}$ & $\begin{array}{r}\begin{array}{r}\text { Terms } \\
\text { of trade } \\
(2000=1 \\
00)\end{array} \\
\end{array}$ \\
\hline 1973 & $\begin{array}{r}192537971 \\
582.56 \\
\end{array}$ & 20.20 & 24.27 & -2.29 & $\begin{array}{r}4231996 \\
6193.04\end{array}$ & $\begin{array}{r}4672631 \\
9206.27 \\
\end{array}$ & $\begin{array}{r}8904628 \\
5399.31 \\
\end{array}$ & 0.462487 & , \\
\hline 1974 & $\begin{array}{r}206131369 \\
798.97 \\
\end{array}$ & 21.98 & 31.01 & -4.74 & $\begin{array}{r}5413472 \\
6975.22 \\
\end{array}$ & $\begin{array}{r}6391300 \\
5142.59 \\
\end{array}$ & $\begin{array}{r}1180477 \\
32117.81 \\
\end{array}$ & 0.572682 & - \\
\hline 1975 & $\begin{array}{r}241756637 \\
168.14\end{array}$ & 26.26 & 26.55 & -1.68 & $\begin{array}{r}6013175 \\
1769.91\end{array}$ & $\begin{array}{r}6418235 \\
5530.97\end{array}$ & $\begin{array}{r}1243141 \\
07300.89\end{array}$ & 0.514212 & - \\
\hline 1976 & $\begin{array}{r}232614555 \\
256.07 \\
\end{array}$ & 24.87 & 28.53 & -1.10 & $\begin{array}{r}6380300 \\
0539.08 \\
\end{array}$ & $\begin{array}{r}6637110 \\
4941.60 \\
\end{array}$ & $\begin{array}{r}1301741 \\
05480.68\end{array}$ & 0.559613 & - \\
\hline 1977 & $\begin{array}{r}263066457 \\
352.17 \\
\end{array}$ & 27.43 & 28.37 & 0.68 & $\begin{array}{r}7642943 \\
6071.86 \\
\end{array}$ & $\begin{array}{r}7463143 \\
2408.86 \\
\end{array}$ & $\begin{array}{r}1510608 \\
68480.73 \\
\end{array}$ & 0.574231 & - \\
\hline 1978 & $\begin{array}{r}335883029 \\
721.96 \\
\end{array}$ & 29.05 & 26.14 & 1.29 & $\begin{array}{r}9213268 \\
9165.87 \\
\end{array}$ & $\begin{array}{r}8781412 \\
0038.35 \\
\end{array}$ & $\begin{array}{r}1799468 \\
09204.22 \\
\end{array}$ & 0.535742 & - \\
\hline 1979 & $\begin{array}{r}438994070 \\
309.19\end{array}$ & 27.43 & 26.45 & 0.36 & $\begin{array}{r}1176927 \\
73401.10\end{array}$ & $\begin{array}{r}1161305 \\
37907.67\end{array}$ & $\begin{array}{r}2338233 \\
11308.77\end{array}$ & 0.532634 & \\
\hline 1980 & $\begin{array}{r}564947710 \\
899.37 \\
\end{array}$ & 26.81 & 23.93 & 2.14 & $\begin{array}{r}1472435 \\
70299.79\end{array}$ & $\begin{array}{r}1351651 \\
71740.65\end{array}$ & $\begin{array}{r}2824087 \\
42040.44\end{array}$ & 0.499885 & 306.1728 \\
\hline 1981 & $\begin{array}{r}540765675 \\
241.16 \\
\end{array}$ & 26.06 & 22.67 & 2.77 & $\begin{array}{r}1375735 \\
79983.92 \\
\end{array}$ & $\begin{array}{r}1226141 \\
46704.18 \\
\end{array}$ & $\begin{array}{r}2601877 \\
26688.10 \\
\end{array}$ & 0.481147 & 357.5758 \\
\hline 1982 & $\begin{array}{r}515048916 \\
841.37 \\
\end{array}$ & 25.44 & 23.24 & 1.86 & $\begin{array}{r}1292799 \\
04088.05 \\
\end{array}$ & $\begin{array}{r}1196771 \\
58455.63 \\
\end{array}$ & $\begin{array}{r}2489570 \\
62543.68 \\
\end{array}$ & 0.483366 & 331.8182 \\
\hline 1983 & $\begin{array}{r}489618008 \\
185.54\end{array}$ & 25.10 & 24.28 & 0.94 & $\begin{array}{r}1235170 \\
42898.29 \\
\end{array}$ & $\begin{array}{r}1188972 \\
39502.80\end{array}$ & $\begin{array}{r}2424142 \\
82401.09\end{array}$ & 0.495109 & 326.6667 \\
\hline 1984 & $\begin{array}{r}461487097 \\
632.35 \\
\end{array}$ & 25.23 & 27.03 & -0.06 & $\begin{array}{r}1244569 \\
23915.94 \\
\end{array}$ & $\begin{array}{r}12471 \\
35328 \\
\end{array}$ & $\begin{array}{r}762 \\
4.48 \\
\end{array}$ & 0.539942 & 282.4561 \\
\hline 1985 & $\begin{array}{r}489285164 \\
271.05 \\
\end{array}$ & 26.97 & 26.23 & 1.09 & $\begin{array}{r}1336428 \\
93223.82 \\
\end{array}$ & $\begin{array}{r}1283304 \\
05544.15 \\
\end{array}$ & $\begin{array}{r}2619732 \\
98767.97 \\
\end{array}$ & 0.53542 & 228 \\
\hline 1986 & $\begin{array}{r}601452653 \\
180.89\end{array}$ & 27.31 & 24.91 & -0.59 & $\begin{array}{r}1463173 \\
72031.66\end{array}$ & $\begin{array}{r}1498456 \\
29434.18\end{array}$ & $\begin{array}{r}2961630 \\
01465.85\end{array}$ & 0.492413 & 142.1053 \\
\hline 1987 & $\begin{array}{r}745162608 \\
269.33 \\
\end{array}$ & 24.33 & 24.77 & -0.91 & $\begin{array}{r}1777655 \\
42572.32 \\
\end{array}$ & $\begin{array}{r}1845797 \\
15312.96 \\
\end{array}$ & $\begin{array}{r}3623452 \\
57885.28 \\
\end{array}$ & 0.486263 & 136.3636 \\
\hline 1988 & $\begin{array}{r}910122732 \\
123.80 \\
\end{array}$ & 23.86 & 24.69 & -3.20 & $\begin{array}{r}1955301 \\
05122.73\end{array}$ & $\begin{array}{r}2246673 \\
72287.44\end{array}$ & $\begin{array}{r}4201974 \\
77410.17\end{array}$ & 0.461693 & 139.3617 \\
\hline 1989 & $\begin{array}{r}926884816 \\
753.93 \\
\end{array}$ & 21.48 & 25.51 & -3.57 & $\begin{array}{r}2033574 \\
96400.52 \\
\end{array}$ & $\begin{array}{r}2364910 \\
17670.16 \\
\end{array}$ & $\begin{array}{r}4398485 \\
14070.68 \\
\end{array}$ & 0.474545 & 136.8421 \\
\hline 1990 & $\begin{array}{r}109316938 \\
9204.55 \\
\end{array}$ & 21.94 & 24.42 & -1.81 & $\begin{array}{r}2471349 \\
00923.30 \\
\end{array}$ & $\begin{array}{r}2669643 \\
98792.61 \\
\end{array}$ & $\begin{array}{r}5140992 \\
99715.91 \\
\end{array}$ & 0.470283 & 156.6038 \\
\hline 1991 & $\begin{array}{r}114279717 \\
8130.51 \\
\end{array}$ & 22.61 & 22.27 & -0.37 & $\begin{array}{r}2502250 \\
66137.57 \\
\end{array}$ & $\begin{array}{r}2544450 \\
71252.21 \\
\end{array}$ & $\begin{array}{r}5046701 \\
37389.77 \\
\end{array}$ & 0.44161 & 142.4528 \\
\hline 1992 & $\begin{array}{r}117965952 \\
9659.53\end{array}$ & 21.90 & 22.91 & -0.70 & $\begin{array}{r}2620455 \\
50193.05\end{array}$ & $\begin{array}{r}2703090 \\
90733.59\end{array}$ & $\begin{array}{r}5323546 \\
40926.64\end{array}$ & 0.451278 & 134.5455 \\
\hline 1993 & $\begin{array}{r}106138872 \\
2255.55\end{array}$ & 22.21 & 24.42 & -0.35 & $\begin{array}{r}2554016 \\
09928.01\end{array}$ & $\begin{array}{r}2591623 \\
70875.83\end{array}$ & $\begin{array}{r}5145639 \\
80803.84\end{array}$ & 0.484803 & 129.7619 \\
\hline 1994 & $\begin{array}{r}114048974 \\
5944.29\end{array}$ & 24.06 & 25.29 & -0.02 & $\begin{array}{r}2882054 \\
68472.61\end{array}$ & $\begin{array}{r}2884457 \\
84205.69 \\
\end{array}$ & $\begin{array}{r}5766512 \\
52678.30\end{array}$ & 0.505617 & 118.8679 \\
\hline 1995 & $\begin{array}{r}133521855 \\
7677.13\end{array}$ & 25.27 & 24.89 & 0.27 & $\begin{array}{r}3359381 \\
41076.22 \\
\end{array}$ & $\begin{array}{r}3322818 \\
36831.31 \\
\end{array}$ & $\begin{array}{r}6682199 \\
77907.53 \\
\end{array}$ & 0.500457 & 125.4386 \\
\hline 1996 & $\begin{array}{r}140878159 \\
1263.65 \\
\end{array}$ & 25.16 & 25.57 & 0.17 & $\begin{array}{r}3625787 \\
83151.33 \\
\end{array}$ & $\begin{array}{r}3601996 \\
87987.52 \\
\end{array}$ & $\begin{array}{r}7227784 \\
71138.85 \\
\end{array}$ & 0.513052 & 147.3684 \\
\hline 1997 & $\begin{array}{r}155248362 \\
8028.81\end{array}$ & 25.74 & 24.89 & 0.40 & $\begin{array}{r}3926866 \\
40471.51\end{array}$ & $\begin{array}{r}3864047 \\
15127.70\end{array}$ & $\begin{array}{r}7790913 \\
55599.21\end{array}$ & 0.501835 & 146.0784 \\
\hline 1998 & $\begin{array}{r}163851109 \\
6389.53 \\
\end{array}$ & 25.29 & 24.53 & -0.79 & $\begin{array}{r}3888721 \\
43093.74 \\
\end{array}$ & $\begin{array}{r}4018979 \\
79463.40 \\
\end{array}$ & $\begin{array}{r}7907701 \\
22557.14 \\
\end{array}$ & 0.482615 & 102.9412 \\
\hline 1999 & $\begin{array}{r}166562368 \\
5487.79\end{array}$ & 23.73 & 25.16 & -1.55 & $\begin{array}{r}3931790 \\
97233.46\end{array}$ & $\begin{array}{r}4190486 \\
97621.74\end{array}$ & $\begin{array}{r}8122277 \\
94855.20\end{array}$ & 0.487642 & 105.0505 \\
\hline 2000 & $\begin{array}{r}164795127 \\
8559.54 \\
\end{array}$ & 23.61 & 26.69 & -1.84 & $\begin{array}{r}4094129 \\
21773.34 \\
\end{array}$ & $\begin{array}{r}4397911 \\
93826.60 \\
\end{array}$ & $\begin{array}{r}8492041 \\
15599.94 \\
\end{array}$ & 0.515309 & 100 \\
\hline 2001 & $\begin{array}{r}162151000 \\
4318.41\end{array}$ & 24.84 & 27.04 & -2.30 & $\begin{array}{r}4011271 \\
05225.28\end{array}$ & $\begin{array}{r}4384986 \\
32503.24\end{array}$ & $\begin{array}{r}8396257 \\
37728.52 \\
\end{array}$ & 0.517805 & 90.86948 \\
\hline
\end{tabular}




\begin{tabular}{|c|c|c|c|c|c|c|c|c|c|}
\hline 2002 & $\begin{array}{r}176840827 \\
3381.29\end{array}$ & 24.74 & 26.57 & -2.80 & $\begin{array}{r}4204121 \\
70263.79\end{array}$ & $\begin{array}{r}4698456 \\
23501.20\end{array}$ & $\begin{array}{r}8902577 \\
93764.99\end{array}$ & 0.503423 & 92.23517 \\
\hline 2003 & $\begin{array}{r}203839510 \\
2040.82\end{array}$ & 23.77 & 25.94 & -2.40 & $\begin{array}{r}4797289 \\
79591.84\end{array}$ & $\begin{array}{r}5286971 \\
42857.14\end{array}$ & $\begin{array}{r}1008426 \\
122448.9 \\
8\end{array}$ & 0.494716 & 100.9348 \\
\hline 2004 & $\begin{array}{r}239855547 \\
4185.28\end{array}$ & 23.53 & 26.07 & -2.63 & $\begin{array}{r}5622867 \\
08165.51\end{array}$ & $\begin{array}{r}6252709 \\
63017.21\end{array}$ & $\begin{array}{r}1187557 \\
671182.7 \\
2\end{array}$ & 0.495114 & 117.617 \\
\hline 2005 & $\begin{array}{r}252070181 \\
8181.82\end{array}$ & 23.44 & 27.25 & -2.57 & $\begin{array}{r}6222381 \\
81818.18\end{array}$ & $\begin{array}{r}6869890 \\
90909.09\end{array}$ & $\begin{array}{r}1309227 \\
272727.2 \\
7\end{array}$ & 0.51939 & 152.9293 \\
\hline 2006 & $\begin{array}{r}269261269 \\
5492.18\end{array}$ & 24.69 & 29.12 & -2.41 & $\begin{array}{r}7191462 \\
74149.03\end{array}$ & $\begin{array}{r}7840183 \\
99264.03\end{array}$ & $\begin{array}{r}1503164 \\
673413.0 \\
6\end{array}$ & 0.558255 & 176.4954 \\
\hline 2007 & $\begin{array}{r}307435974 \\
3897.56\end{array}$ & 26.71 & 27.34 & -2.48 & $\begin{array}{r}7643717 \\
48699.48\end{array}$ & $\begin{array}{r}8405082 \\
03281.31\end{array}$ & $\begin{array}{r}1604879 \\
951980.7 \\
9\end{array}$ & 0.522021 & 181.6111 \\
\hline 2008 & $\begin{array}{r}289056433 \\
8235.29\end{array}$ & 24.86 & 29.67 & -2.87 & $\begin{array}{r}7747113 \\
97058.82\end{array}$ & $\begin{array}{r}8575294 \\
11764.71\end{array}$ & $\begin{array}{r}1632240 \\
808823.5 \\
3\end{array}$ & 0.564679 & 223.3731 \\
\hline 2009 & $\begin{array}{r}238282598 \\
5355.97\end{array}$ & 26.80 & 28.32 & -2.19 & $\begin{array}{r}6226032 \\
09222.62\end{array}$ & $\begin{array}{r}6747188 \\
03551.96\end{array}$ & $\begin{array}{r}1297322 \\
012774.5 \\
8 \\
\end{array}$ & 0.544447 & 157.9378 \\
\hline 2010 & $\begin{array}{r}244117339 \\
4729.62\end{array}$ & 26.13 & 30.82 & -2.61 & $\begin{array}{r}6887549 \\
84314.56\end{array}$ & $\begin{array}{r}7523664 \\
08693.95\end{array}$ & $\begin{array}{r}1441121 \\
393008.5 \\
1 \\
\end{array}$ & 0.59034 & 191.8977 \\
\hline 2011 & $\begin{array}{r}261970040 \\
4733.37\end{array}$ & 28.21 & 32.05 & -1.54 & $\begin{array}{r}7992779 \\
37659.92\end{array}$ & $\begin{array}{r}8396069 \\
76489.97\end{array}$ & $\begin{array}{r}1638884 \\
914149.8 \\
9\end{array}$ & 0.6256 & 225.3154 \\
\hline 2012 & $\begin{array}{r}266208516 \\
8498.93\end{array}$ & 30.51 & 31.71 & -1.98 & $\begin{array}{r}7914973 \\
27717.21\end{array}$ & $\begin{array}{r}8442011 \\
56322.77\end{array}$ & $\begin{array}{r}1635698 \\
484039.9 \\
7 \\
\end{array}$ & 0.614443 & 227.2532 \\
\hline 2013 & $\begin{array}{r}273981868 \\
0930.19\end{array}$ & 29.73 & 31.68 & -2.02 & $\begin{array}{r}8127951 \\
26346.15\end{array}$ & $\begin{array}{r}8680853 \\
86896.45\end{array}$ & $\begin{array}{r}1680880 \\
513242.6 \\
0\end{array}$ & 0.613501 & 223.8164 \\
\hline 2014 & $\begin{array}{r}302282778 \\
1881.39\end{array}$ & 29.67 & 30.25 & -2.00 & $\begin{array}{r}8538747 \\
77613.82\end{array}$ & $\begin{array}{r}9144790 \\
30510.28\end{array}$ & $\begin{array}{r}1768353 \\
808124.1 \\
0 \\
\end{array}$ & 0.585 & 209.2686 \\
\hline 2015 & $\begin{array}{r}288557030 \\
9160.86\end{array}$ & 28.25 & 29.10 & -1.71 & $\begin{array}{r}7901070 \\
53896.83\end{array}$ & $\begin{array}{r}8395612 \\
18721.02\end{array}$ & $\begin{array}{r}1629668 \\
272617.8 \\
5\end{array}$ & 0.564765 & 134.5188 \\
\hline 2016 & $\begin{array}{r}265085017 \\
8102.14\end{array}$ & 27.38 & 30.33 & -2.07 & $\begin{array}{r}7490037 \\
62572.53\end{array}$ & $\begin{array}{r}8039255 \\
92427.63\end{array}$ & $\begin{array}{r}1552929 \\
355000.1 \\
6 \\
\end{array}$ & 0.585823 & 121.2276 \\
\hline 2017 & $\begin{array}{r}262243395 \\
9604.16\end{array}$ & 28.26 & 31.93 & -1.40 & $\begin{array}{r}8005932 \\
04589.45\end{array}$ & $\begin{array}{r}8374270 \\
58259.18\end{array}$ & $\begin{array}{r}1638020 \\
262848.6 \\
3\end{array}$ & 0.624618 & - \\
\hline
\end{tabular}

Source: Developed by authors based on World Bank (1-7). 2018 
Appendix 2. GDP Growth in Medium Run for Specific Country Groupings

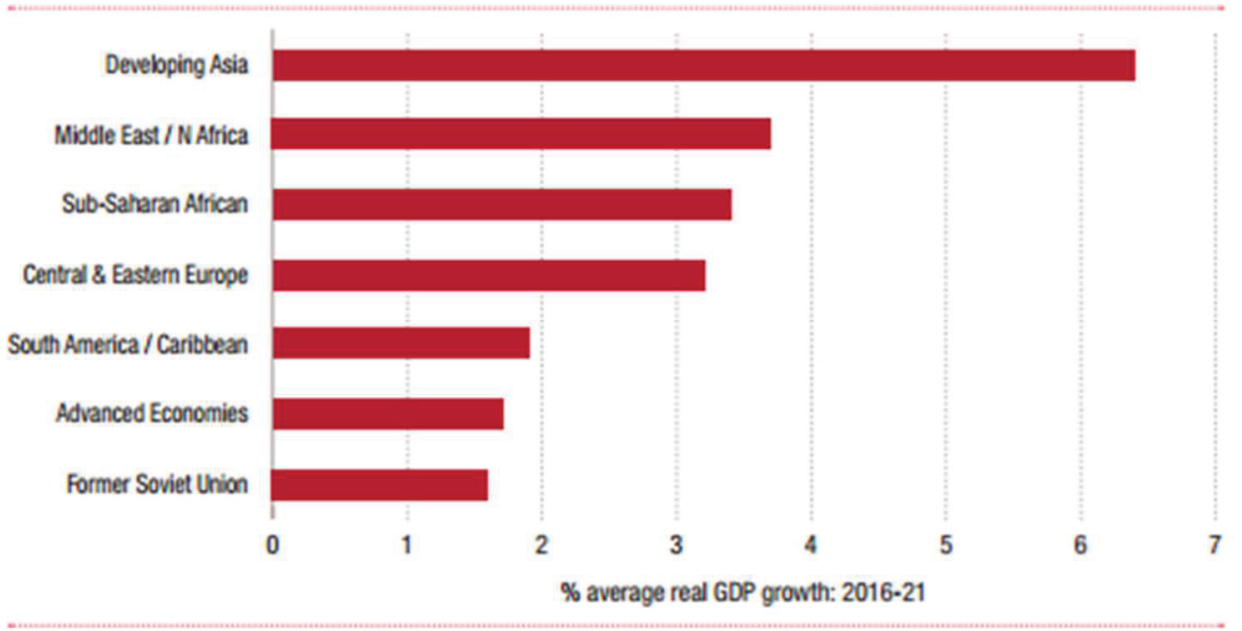

Source: IMF World Economic Outlook. 2016

Appendix 3. United Kingdom Exports By Country by 2030

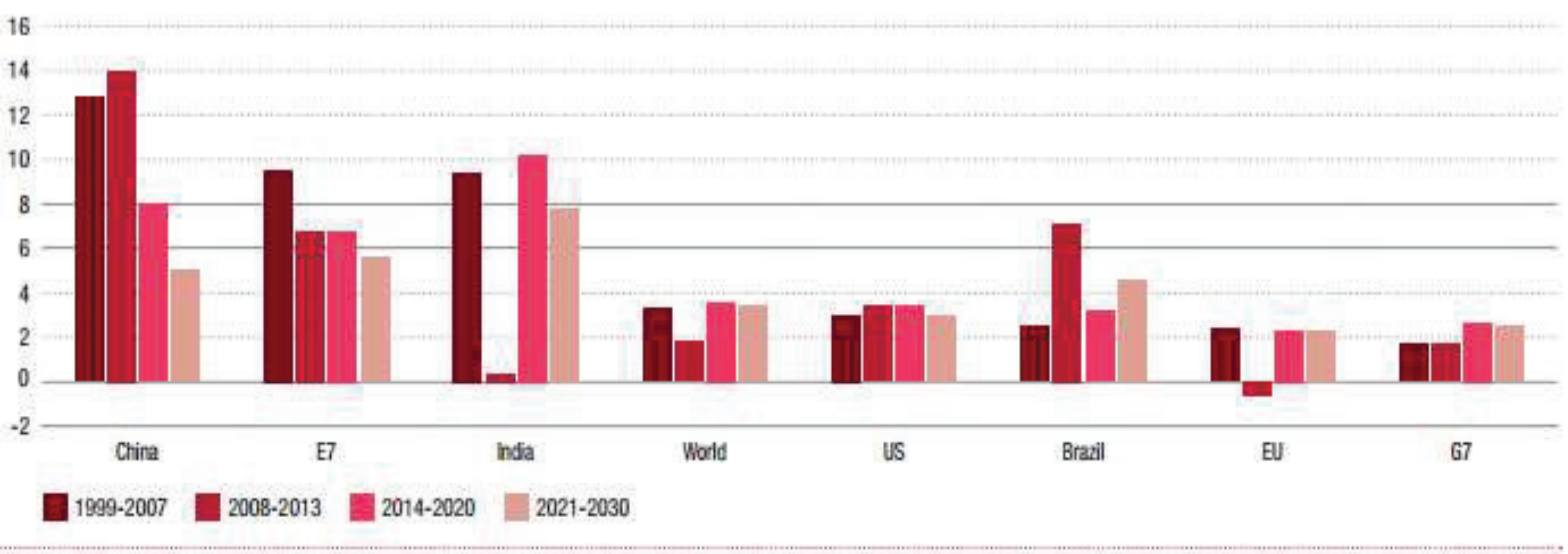

Source: Sentance. 2016

Appendix 4. Export destinations of the United Kingdom by 2030

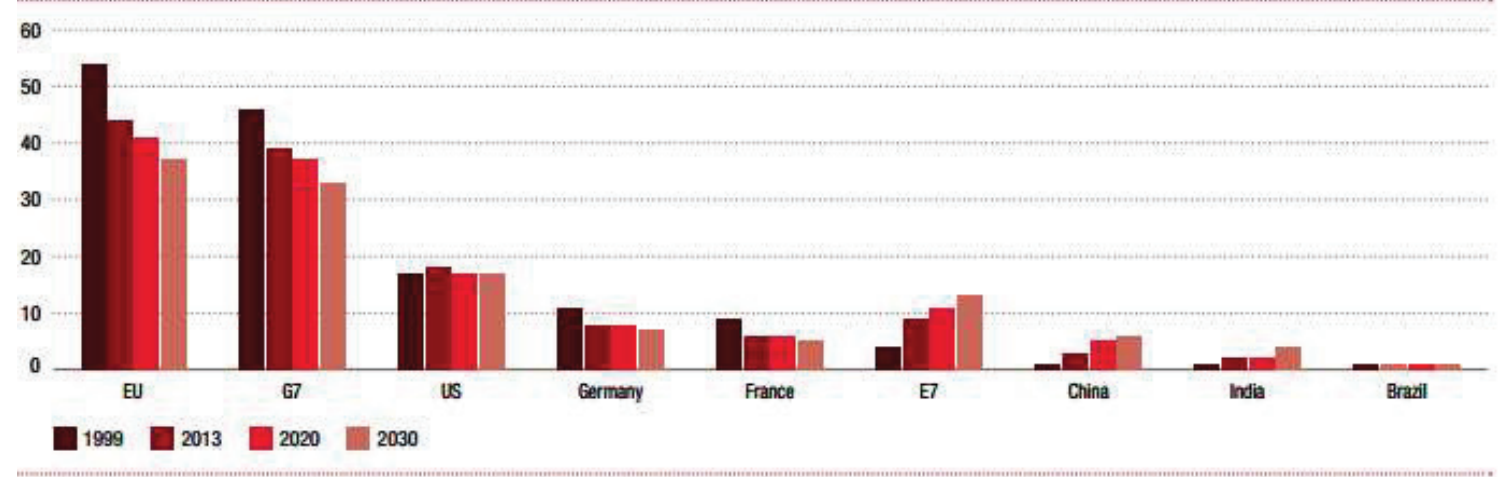

Source: Sentance. 2016 